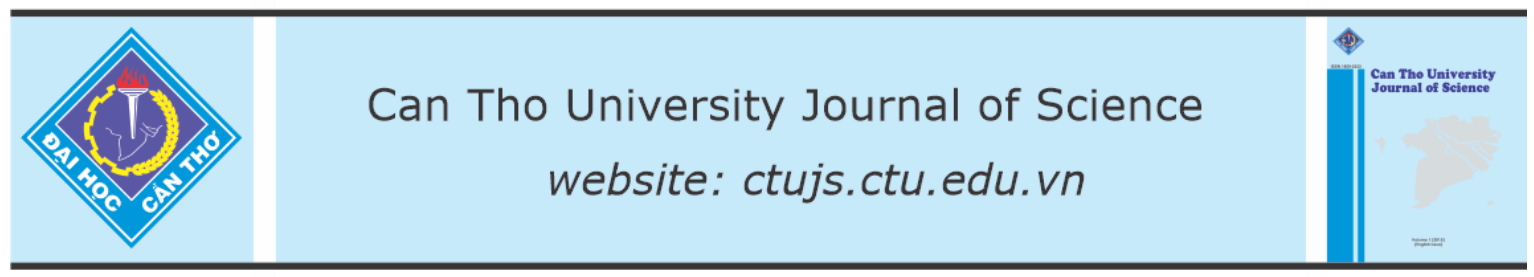

DOI: 10.22144/ctu.jen.2021.035

\title{
Effects of different temperatures on the growth and survival of mud crab (Scylla paramamosain) larvae
}

Nguyen Thanh Phuong*, Nguyen Tinh Em, Nguyen Thi Kim Ha, Le Quoc Viet and

Do Thi Thanh Huong

College of Aquaculture and Fisheries, Can Tho University, Viet Nam

*Correspondence: Nguyen Thanh Phuong (email: ntphuong@ctu.edu.vn)

\section{Article info.}

Received 21 Aug 2021

Revised 11 Sep 2021

Accepted 18 Nov 2021

\section{Keywords}

Growth, Scylla

paramamosain, survival rate, temperature

\begin{abstract}
This study aimed to evaluate the effects of temperature on the growth and survival of mud crab (Scylla paramamosain) larvae in two stages including zoea-1 to megalopa (the first experiment) and megalopa to crablet-1 (the second experiment). Each experiment was conducted in a completely randomized design with four temperature levels $\left(27,30,33\right.$, and $\left.36^{\circ} \mathrm{C}\right)$ in triplicate. Stocking density of 200 ind./L for the first experiment and 4 ind./L for the second experiment. Fiberglass tanks of 500-L (containing 300-L and 250-L of 25\% water for the first and second experiment, respectively) were used in the experiments. The results showed that $S$. paramamosain larvae at zoea-3 and zoea-4 died at $33^{\circ} \mathrm{C}$ or above, while the highest survival rate of this stage was found at $27^{\circ} \mathrm{C}(11.5 \%)$. The growth and larval stage index during the zoea to megalopa stage were significantly higher in $30^{\circ} \mathrm{C}(p<0.05)$ compared to those in the $27^{\circ} \mathrm{C}$ treatment. In the second experiment, the survival rates of crablet-1 were highest $(72.9 \%)$ at $27^{\circ} \mathrm{C}$ and lowest $(34,7 \%)$ at $36^{\circ} \mathrm{C}$. The growth rate of crablets at this stage increased with increased temperature. The highest carapace width and weight $(3.41 \mathrm{~mm}$ and $0.030 \mathrm{~g}$, respectively) were recorded at $36^{\circ} \mathrm{C}$. The findings of this study suggested that mud crab larvae should be reared at the temperature range of $27-30^{\circ} \mathrm{C}$ to maximize their production.
\end{abstract}

\section{INTRODUCTION}

Temperature is considered one of the most important factors influencing marine species (Ponce-Palafox et al., 1997). Temperature is determined to be the most important modifier of energy flow and growth of aquatic animals (Brett, 1979). Temperature can affect the survival and development of crustaceans (Ruscoe et al., 2004; Kuhn, 2017). Their intermolt periods have been reported to be influenced by temperature (Leffler, 1972; Wainwright \& Armstrong, 1993). Effects of temperature on the development and survival of
Scylla serrata and $S$. paramamosain were welldocumented in numerous published papers (Hill, 1974; Hill, 1980; Heasman \& Fielder, 1983; Chen \& Cheng, 1985; Zeng \& Li, 1992; Nurdiani \& Zeng, 2007; Do et al., 2020). Hamasaki (2003) found that the best temperature for survival of $S$. serrata larvae was $29^{\circ} \mathrm{C}$, and the duration of larval rearing was significantly shortened with increasing temperature between $23^{\circ} \mathrm{C}$ and $32^{\circ} \mathrm{C}$.

S. paramamosain is a common species found in the lower Mekong delta, Vietnam (Macintosh et al., 2002). It has received increasing attention for its 
great taste, abundant nutrients, and medicinal uses (Wang et al., 2005; Ma et al., 2014). In the last decade, $S$. paramamosain showed its potential to contribute to aquaculture development in the future. The Mekong delta had 100 hatcheries, which produced around 200,000 juveniles/hatchery/year in 2009 (Tran \& Nguyen, 2009). The number of $S$. paramamosain hatcheries significantly increased, reaching 480 in 2017 with the yearly production per hatchery ranging from 0.5 to 12 million crablets (Tran et al., 2017). S. paramamosain farming has been rapidly growing but is being predicted to be affected by climate change under increasing temperatures. According to IPCC (2018), the global temperature could increase from $2^{\circ} \mathrm{C}$ to $2.8^{\circ} \mathrm{C}$ in 2100 , in which the Mekong delta was predicted to increase to over $32^{\circ} \mathrm{C}$ by 2050 (Mainuddin et al., 2010). Previously, studies on S. paramamosain have mainly focused on nutrition, seed production, rearing system, and digestive enzyme activities (Tran \& Le, 2017; Tran, 2017; Tran et al., 2019; Tran, 2018). In an in vitro study, the embryonic development duration increases with the decrease in temperature, which is 9 days at $30^{\circ} \mathrm{C}$ compared to almost one month at $20^{\circ} \mathrm{C}$ (Zeng, 2007). Do et al. (2020) suggested that the temperature range of 27 to $30^{\circ} \mathrm{C}$ is optimal for mud crab juvenile culture. However, knowledge of the impacts of temperature on this species, especially at larval stages is unknown. To provide more information and guidelines for $S$. paramamosain production by elucidating optimal water requirements, the present study investigated the effects of different temperature levels on growth performance and survival of $S$. paramamosain at the larval stages.

\section{MATERIALS AND METHODS}

\subsection{Animals and Materials}

S. paramamosain gravid females were obtained from $\mathrm{Ca} \mathrm{Mau}$ province in the Mekong Delta, Vietnam. The animals were held in a 100-L tank in the wet laboratory of the College of Aquaculture and Fisheries, Can Tho University for 12 hours at 25\%o and $27^{\circ} \mathrm{C}\left( \pm 1^{\circ} \mathrm{C}\right)$. Female crabs with full appendices and active movement were selected for spawning in aquaria (one female per aquarium). Active swimming zoeal larvae were collected by siphoning with an aeration tube and transferred into the rearing tanks.

Brine water of $90 \%$ was obtained from a salt field in Soc Trang province, a coastal province in the Mekong delta. Brine water was orderly diluted to $25 \%$, treated with chlorine (concentration of 50 $\mathrm{mg} / \mathrm{L}$ ), and filtered through a $5 \mu \mathrm{m}$ bag before use. The temperature treatments of 30,33 , and $36^{\circ} \mathrm{C}$ were controlled by the heaters (ATMAN CH $200 \mathrm{~W}$ ), and $27^{\circ} \mathrm{C}$ was maintained by the chiller (Teco Seachill TR-10).

\subsection{Experimental design}

The study was conducted over two periods of larval development including (1) from zoea-1 to megalopa stage; and (ii) from megalopa to the crablet-1 stage. All experiments were conducted in a completely randomized design with three replicates per treatment.

Effects of temperature on the development of $S$. paramamosain larvae from zoea-1 to megalopa stage: Larvae were randomly distributed into 12 tanks (containing 300-L of water), representing four temperature treatments including $27^{\circ} \mathrm{C}$ as control; $30 ; 33$ and $36^{\circ} \mathrm{C}$ with three replicates. The larval density was 200 ind./L (60,000 larvae/tank).

Effects of temperature on the development of $S$. paramamosain from megalopa to crablet-1 stage: Megalopa metamorphosed from zoea-5 were immediately distributed into 12 tanks (containing 250-L of water), representing four temperature treatments as described in the first experiment. The density was 4 megalopa/L (1.000 ind./tank).

After stocking, the temperature in every single treatment was increased in different stepwise following experimental temperature treatments $\left(1^{\circ} \mathrm{C} / 16\right.$ hours in $30^{\circ} \mathrm{C}$ treatment, $1^{\circ} \mathrm{C} / 8$ hours in $33^{\circ} \mathrm{C}$ treatment, and $1{ }^{\circ} \mathrm{C} / 5.3$ hours in $36^{\circ} \mathrm{C}$ treatment).

Water was renewed every three days at the ratio of $30 \%$ of water in the tanks. The nauplius of Artemia (Vinh Chau brand, produced and packaged by the College of Aquaculture and Fisheries, Can Tho University) was used as live food. Umbrella stage Artemia was used for larvae from zoea-1 to zoea-3 stage with 8 feedings a day (at 0:00, 3:00, 6:00, 9:00, 12:00, 15:00, 18:00 and 21:00) (equal to $2 \mathrm{~g}$ cyst $/ \mathrm{m}^{3}$ ). At the zoea-4 stage, the larvae were fed with Frippak PL+150 (a commercial shrimp larvae feed of INVE Aquaculture) with $1 \mathrm{~g} / \mathrm{m}^{3}$ at $6: 00$ and 18:00, while Artemia at newly hatched stage was used for the other feeding times (equal to $4 \mathrm{~g}$ cyst $/ \mathrm{m}^{3}$ ). From zoea-5 to early megalopa stage, Lansy-shrimp PL (a commercial shrimp of INVE Aquaculture) was fed $1 \mathrm{~g} / \mathrm{m}^{3}$ at 0:00, 6:00, 12:00, and 18:00. and newly hatched Artemia (equal to 6 $\mathrm{g} / \mathrm{m}^{3}$ ) was used at 3:00, 9:00, 15:00, and 21:00. From the megalopa to the crablet-1 stage, crabs were 
completely fed $100 \%$ Lansy-shrimp PL (1-2 g/m $\left.\mathrm{m}^{3}\right)$. At this stage, $4 \mathrm{~m}^{2}$ plastic nets (mesh size of $5 \mathrm{~cm}$ ) were placed in the tanks to serve as shelters to reduce cannibalism by increasing available surface area and reducing the encounters among crabs.

Dissolved oxygen (DO) and $\mathrm{pH}$ were measured daily using WTW Multi Oxi 3206 and WTW Multi 3510 IDS, with values ranging from 7.57 to 7.73 $\mathrm{mg} / \mathrm{L}$ and 7.5 to 7.8 , respectively. Salinity was also checked daily using a handheld refractometer (RES10ATC). TAN and nitrite $\left(\mathrm{NO}_{2}{ }^{-}\right)$concentrations were analyzed weekly using methods of Griess Ilosvay, and Diazonium, and Indophenol blue. Nitrite concentration fluctuated between 0.4 and 0.5 $\mathrm{mg} / \mathrm{L}$, while TAN ranged between 0.07 and 0.09 $\mathrm{mg} / \mathrm{L}$. Throughout the experiments, the water quality parameters were acceptable for the ideal culture conditions in mud crab (Shelley \& Lovatelli, 2011; Dat, 2004; Seneriches-Abiera et al., 2007; FAO, 2007).

\subsection{Growth and metamorphosis observation}

Larval stage index and growth of zoea were measured every three days by randomly collecting 20 individuals per tank. A microscope with an eyepiece ruler reticle (Olympus SZ51) was used to determine the developmental stages. For the growth of crablet-1, weight and carapace width (at the base of the lateral spines) were individually determined by weighing and measuring 30 crabs per replicate, respectively.

Survival rates $(\%)$ were determined as the number of larvae that successfully molted to the megalopa stage (the first experiment) and the crablet- 1 (the second experiment) over the total number of stocked larvae in each replicate.

These parameters were calculated by the following formulas:
Larval stage index (LSI)

$\mathrm{LSI}=\frac{(\mathrm{N} 1 \times \mathrm{n} 1)+(\mathrm{N} 2 \times \mathrm{n} 2)+(\mathrm{Ni} \times \mathrm{ni})}{(\mathrm{n} 1+\mathrm{n} 2+\mathrm{ni})}$

Where: N1, N2, Ni: stage of larvae; n1, n2, ni: the number of larvae of each stage.

Survival rate (SR)

$\mathrm{SR}(\%)=\frac{\text { Final number of larvae }}{\text { Initial numbers of larvae }} \times 100$

\subsection{Statistical analysis}

All the data were subjected to statistical analysis involving standard deviation (SD) and mean (M) using Excel 2016. One-way and T-Test analysis of variance (ANOVA) together with DUNCAN's posthoc tests were used to test for significant differences (at a significant level of 0.05) using the SPSS 16.0.

\section{RESULTS}

\subsection{Effects of temperature on the development of $S$. paramamosain larvae from zoea-1 to megalopa stage.}

\subsubsection{Metamorphosis of the S. paramamosain larvae}

The larval stage index (LSI) varied from $1.0 \pm 0.00$ to $1.3 \pm 0.12$ on day 3 . LSI was significantly highest at $36^{\circ} \mathrm{C} \quad(\mathrm{p}<0.05)$. The impact of temperature on metamorphosis was clearly shown on day 6 with LSI values increasing with temperatures. The same trend was repeated on days $9,12,15$, and 18 . It is noticed that $S$. paramamosain larvae in $36^{\circ} \mathrm{C}$ only survived to day 6 with zoea- 2 and zoea- 3 stages, while all the larvae reared at $33^{\circ} \mathrm{C}$ died after 9 days of exposure when crabs developed from zoea- 3 to zoea-4 stage. After 18 days of rearing, the LSI in $30^{\circ} \mathrm{C}$ treatment $(6.18 \pm 0.05)$ was significantly higher than that in $27^{\circ} \mathrm{C}(5.80 \pm 0.05)$ (Table 1).

Table 1. Larval stage index (LSI) of $S$. paramamosain larvae from zoea-1 to megalopa stage under different temperatures

\begin{tabular}{crrrr}
\hline \multirow{2}{*}{ Day } & $\mathbf{2 7}^{\circ} \mathbf{C}$ & Treatments & $\mathbf{3 6}^{\circ} \mathbf{C}$ \\
\cline { 2 - 5 } & $1.00 \pm 0.00^{\mathrm{a}}$ & $1.00 \pm 0.00^{\mathrm{a}}$ & $1.1 \pm 0.02^{\mathrm{a}}$ & $1.3 \pm 0.12^{\mathrm{b}}$ \\
3 & $1.68 \pm 0.77^{\mathrm{a}}$ & $2.00 \pm 0.00^{\mathrm{b}}$ & $2.65 \pm 0.15^{\mathrm{c}}$ & $3.00 \pm 0.00^{\mathrm{d}}$ \\
6 & $3.00 \pm 0.00^{\mathrm{a}}$ & $3.23 \pm 0.76^{\mathrm{b}}$ & $3.83 \pm 0.17^{\mathrm{c}}$ & \\
9 & $4.10 \pm 0.42^{\mathrm{a}}$ & $4.45 \pm 0.32^{\mathrm{b}}$ & & \\
15 & $5.06 \pm 0.05^{\mathrm{a}}$ & $5.35 \pm 0.05^{\mathrm{b}}$ & & \\
18 & $5.80 \pm 0.05^{\mathrm{a}}$ & $6.18 \pm 0.05^{\mathrm{b}}$ & & \\
\hline
\end{tabular}

Values are expressed as mean $\pm S D$. Different letters $(a, b, c, d)$ in the same rows signify a significant difference $(p<0.05)$. 


\subsubsection{Growth of S. paramamosain larvae at different sampling times}

The results reveal that the length of the larvae was improved with increased temperature. After 3 and 6 days, the $36^{\circ} \mathrm{C}$ treatment showed the highest length $(1.75 \pm 0.01 \mathrm{~mm}$ and $2.58 \pm 0.13 \mathrm{~mm}$, respectively) which was significantly higher than those of other treatments, while the lowest length was found in the control treatment $\left(27^{\circ} \mathrm{C}\right) \quad(1.59 \pm 0.02 \mathrm{~mm}$ and
$1.84 \pm 0.01 \mathrm{~mm}$, respectively). No larvae survived in the $36^{\circ} \mathrm{C}$ treatment on day $9^{\text {th }}$, leaving the $33^{\circ} \mathrm{C}$ treatment had the highest length $(3.95 \pm 0.12 \mathrm{~mm})$ on day $9^{\text {th }}$, compared to other treatments. On day $12^{\text {th }}$, only crabs at $27^{\circ} \mathrm{C}$ and $30^{\circ} \mathrm{C}$ survived and the higher temperatures showed a better growth rate. It indicates that $S$. paramamosain larvae could not survive at $33^{\circ} \mathrm{C}$ or above, and the length values of larvae in the $30^{\circ} \mathrm{C}$ treatment were lower than the control treatment on day $15^{\text {th }}$ and $18^{\text {th }}$ (Table 2$)$.

Table 2. Length of larvae ( $\mathrm{mm})$ from zoea-1 stage to megalopa stage

\begin{tabular}{crrrr}
\hline \multirow{2}{*}{ Day } & \multicolumn{5}{c}{ Treatments } \\
\cline { 2 - 5 } & $\mathbf{2 7}^{\circ} \mathbf{C}$ & $\mathbf{3 0}^{\circ} \mathbf{C}$ & $\mathbf{3 3}^{\circ} \mathbf{C}$ & $\mathbf{3 6}^{\circ} \mathbf{C}$ \\
\hline 3 & $1.59 \pm 0.02^{\mathrm{a}}$ & $1.67 \pm 0.02^{\mathrm{b}}$ & $1.68 \pm 0.01^{\mathrm{c}}$ & $1.75 \pm 0.01^{\mathrm{d}}$ \\
6 & $1.84 \pm 0.01^{\mathrm{a}}$ & $1.94 \pm 0.02^{\mathrm{a}}$ & $2.18 \pm 0.02^{\mathrm{b}}$ & $2.58 \pm 0.13^{\mathrm{c}}$ \\
9 & $2.92 \pm 0.03^{\mathrm{a}}$ & $3.50 \pm 0.03^{\mathrm{b}}$ & $3.95 \pm 0.12^{\mathrm{c}}$ & \\
12 & $4.01 \pm 0.04^{\mathrm{a}}$ & $4.59 \pm 0.04^{\mathrm{b}}$ & & \\
15 & $4.61 \pm 0.01^{\mathrm{b}}$ & $4.51 \pm 0.04^{\mathrm{a}}$ & & \\
18 & $4.22 \pm 0.03^{\mathrm{b}}$ & $4.13 \pm 0.02^{\mathrm{a}}$ & & \\
\hline
\end{tabular}

Values are expressed as mean $\pm S D$. Values with different letters $(a, b, c, d)$ in the rows signify a significant difference $(p<0.05)$.

\subsubsection{Survival rate}

The survival rate of larvae in the $27^{\circ} \mathrm{C}$ treatment $(11.5 \pm 1.08 \%)$ was significantly higher than that of

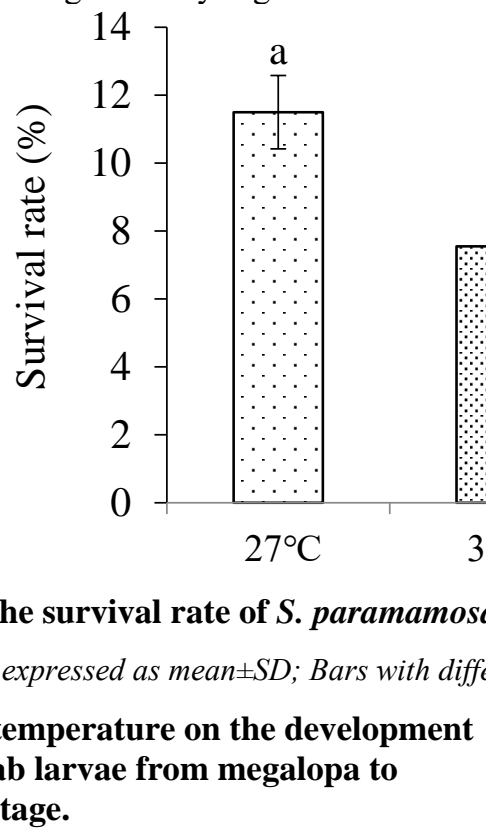

The temperature had shown influences on the growth performance of the megalopa stage. The growth in carapace width as well as in weight increased with increased temperature levels (Table

\subsubsection{Growth of S. paramamosain reared in \\ different temperatures \\ 3.2. Effects of temperature on the development of mud crab larvae from megalopa to crablet-1 stage.}

the $30^{\circ} \mathrm{C}$ treatment $(7.5 \pm 0.04 \%)$. In this study, all the larvae in the 36 and $33^{\circ} \mathrm{C}$ treatments died after 6 and 9 days, respectively (Fig. 1).

Fig. 1. The survival rate of $S$. paramamosain larvae was reared at different temperatures

(Values are expressed as mean $\pm S D$; Bars with different letters $(a, b)$ signify a significant difference, $p<0.05$ )

$\mathrm{b}$

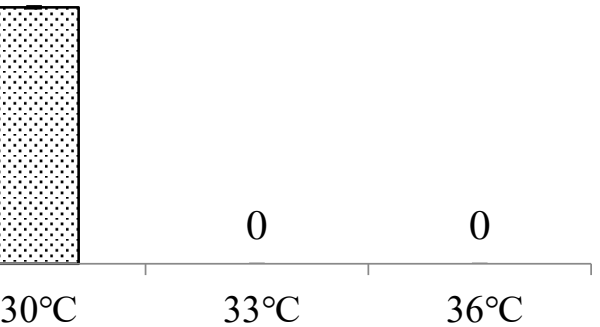

$3)$. The highest values were in $36^{\circ} \mathrm{C}$ treatment ( $3.41 \pm 012 \mathrm{~mm}, 0.030 \pm 0.12 \mathrm{~g}$, respectively) which were significantly higher than the three lower temperature treatments, with the lowest being recorded in the treatment of $27^{\circ} \mathrm{C}(2.13 \pm 0.086 \mathrm{~mm}$, $0.020 \pm 0.04 \mathrm{~g}$, respectively). It is noticeable that the megalopa reared at $27^{\circ} \mathrm{C}$ and $30^{\circ} \mathrm{C}$ showed insignificant differences in both growth rate indicators $(p>0.05)$. 
Table 3. Weight and carapace width $(\mathrm{CW})$ of $S$. paramamosain

\begin{tabular}{lrrrr}
\hline \multirow{2}{*}{ Parameters } & \multicolumn{4}{c}{ Treatments } \\
\cline { 2 - 5 } & $\mathbf{2 7}^{\circ} \mathbf{C}$ & $\mathbf{3 0}^{\circ} \mathbf{C}$ & $\mathbf{3 3}^{\circ} \mathbf{C}$ & $\mathbf{3 6}^{\circ} \mathbf{C}$ \\
\hline Carapace width $(\mathrm{mm})$ & $2.13 \pm 0.086^{\mathrm{a}}$ & $2.5 \pm 0.40^{\mathrm{ab}}$ & $2.90 \pm 0.11^{\mathrm{b}}$ & $3.41 \pm 012^{\mathrm{c}}$ \\
Weight $(\mathrm{g})$ & $0.020 \pm 0.04^{\mathrm{a}}$ & $0.023 \pm 0.01^{\mathrm{ab}}$ & $0.024 \pm 0.00^{\mathrm{b}}$ & $0.030 \pm 0.12^{\mathrm{c}}$ \\
\hline
\end{tabular}

Values are expressed as mean $\pm S D$. Different letters $(a, b, c)$ in the rows signify a significant difference $(p<0.05)$.

\subsubsection{Survival rate}

After 7 days of rearing, there were significant differences among temperature treatments. Survival rates decreased when temperature increased. The highest rate $(72.9 \%)$ was recorded in the $27^{\circ} \mathrm{C}$ treatment which was significantly higher than those of the other three treatments. It is clearly shown that the survival rate of the megalopa reared at $36^{\circ} \mathrm{C}$ was reduced dramatically, just $34.7 \%$ (Fig.2). In general, the temperature had shown its effects on the survival rate of mud crab from megalopa to crablet-1 stage.

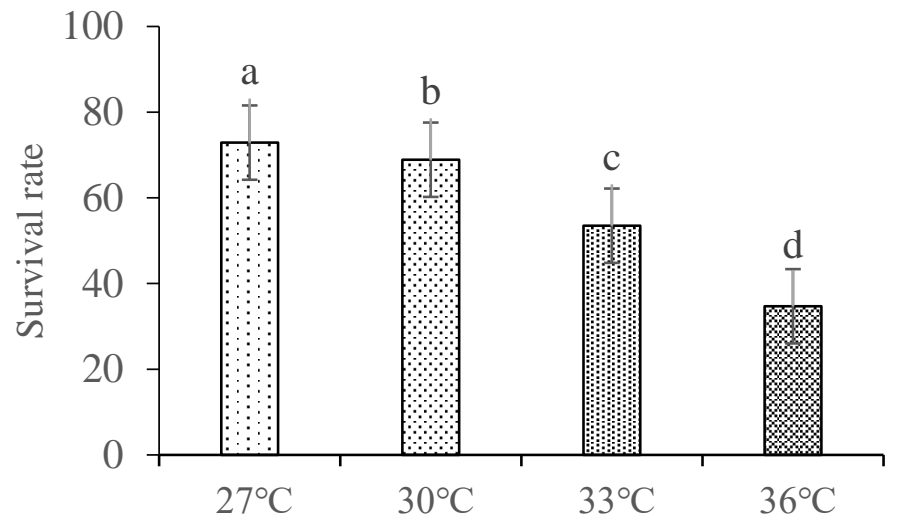

Fig. 2. The survival rate of $S$. paramamosain crablet-1 under different temperatures

(Values are expressed as mean $\pm S D$; Bars with different letters $(a, b, c, d)$ signify a significant difference, $p<0.05$ ).

\section{DISCUSSION}

Van-Wormhoudt and Bellon-Humbert (1994) reported that in crustaceans, raised temperatures and proper light intensity increase their molt frequency, while lower temperature prolongs metamorphosis time. Metamorphosis was recorded to be faster with increased temperature (Marichamy \& Rapackiam, 1991). According to Smith's crustacean moltprocess model, the accumulation of sufficient degree-day exposure is one of the necessary conditions for molting (Smith, 1997). Zeng and Li (1992) stated that the metamorphosis of $S$. serrata larvae was faster in higher temperatures. The results are in agreement with the previous studies carried out on the same species that the length of larvae increased from zoea-1 to zoea-5 stage then decreased at megalopa and crablet-1 stages with values of $1.65 ; 2.18 ; 2.70 ; 3.54 ; 4.50,4.01$, and $2-3$ mm (Nguyen \& Tran, 2009; Tran \& Truong, 2004). In this study, under the impact of temperature, the LSI value in the $30^{\circ} \mathrm{C}$ treatment was higher than in the control $\left(27^{\circ} \mathrm{C}\right)$ treatment.
It is quite different from other species in that growth is continuous (von Bertalanffy, 1938). For crustaceans, growth is discrete and biphasic, and their rigid exoskeleton limits external growth to the brief molting events (Hartnoll, 1982; Brylawski \& Miller, 2006). In the current study, on the same monitoring day the higher the LSI values were, the longer the length of the zoea was observed. The present study also indicates that metamorphosis might appear sooner in the higher temperature treatment resulting in higher growth of the larvae. The zoea nursed at $33^{\circ} \mathrm{C}$ and $36^{\circ} \mathrm{C}$ metamorphosed faster, but they completely died after 6 days and 9 days, respectively. This suggests that the suitable temperature condition for mud crab from the zoea- 1 stage to the megalopa stage was in the range of 27$30^{\circ} \mathrm{C}$. The rising temperature leads to increases in metabolic rate and digestive enzyme activities; fish effectively consume more feed to meet energy demand Do \& Nguyen, 2010). This could partially explain the higher growth rate of mud crabs. These results are also in agreement with the study carried out by Do et al. (2020) that the growth rate of 
crablet-1 increases with temperature levels. In addition, $\alpha$-amylase and trypsin activities are impacted by elevated temperatures, which were significantly higher than those of lower temperatures (Do et al., 2020).

The growth performance of $S$. paramamosain in the current work showed that larvae reared in higher temperature conditions presented a better growth rate with shortened larval development time. Although at the $30^{\circ} \mathrm{C}$ treatment, the length of larval from zoea-1 stage to megalopa stage was longer than that in $27^{\circ} \mathrm{C}$, the survival rate was lower. This was explained that there can be significant cannibalism of mud crab larvae when metamorphosing from zoea-5 to megalopa stage (Shelley \& Lovatelli, 2011). In addition, Azra et al. (2018) documented that active swimming and mobility create greater chances of fighting and cannibalism resulting in higher mortality in blue swimmer crab (Portunus pelagicus) at high temperatures. The higher mortality could be attributed to incidents of molt death syndrome (MDS), describing as larval mortality because they are not able to completely shed their old exoskeleton during molting. MDS was observed to contribute significantly to high zoea-5 of $S$. serrata mortalities at $34^{\circ} \mathrm{C}$ (Nurdiani and Zeng, 2007). Besides, Zeng and $\mathrm{Li}$ (1992) reported that high temperature could also trigger high incidents of MDS and the rate of successful metamorphosis from zoea-5 to megalopa of $S$. serrata decreased as temperatures exceeded $30^{\circ} \mathrm{C}$. A similar result was also found in Penaeus monodon at the juvenile stage, the lowest survival rate was reared at $36^{\circ} \mathrm{C}$ treatment $(0 \%)$, while the highest rate was in the $27^{\circ} \mathrm{C}$ treatment $(65 \%$ ) (Do et al. 2018).

The temperature was by far the most significant factor affecting the survival and growth performance of mud crab in this study. Similar results were found by Ruscoe et al. (2004) that $S$. serrata larvae (crablet- 2 stage) reared at $30^{\circ} \mathrm{C}$ show the highest growth rate and shortest intermolt duration in comparison with those of lower (20 and $\left.25^{\circ} \mathrm{C}\right)$ or higher $\left(35^{\circ} \mathrm{C}\right)$ temperatures. In the current study, the elevated temperature resulted in decreases in the survival rate of larvae from megalopa to crablet- 1 stage, whereby the survival rate at 33 and $36^{\circ} \mathrm{C}$ were $53.5 \%$ and $34.7 \%$ as compared to $72.9 \%$

\section{REFERENCES}

Azra, M. N., Chen, J. C., Ikhwanuddin, M., \& AbolMunafi, A. B. (2018). Thermal tolerance and and $68.9 \%$ at $27^{\circ} \mathrm{C}$ and $30^{\circ} \mathrm{C}$ treatments, respectively. Although the $S$. paramamosain larvae in the 33 and $36^{\circ} \mathrm{C}$ treatments displayed high carapace width and weight values, their survival rates were lower than those in the 27 and $30^{\circ} \mathrm{C}$ treatments. This result showed that the best temperature range for rearing megalopa to crablet-1 stage is 27 to $30^{\circ} \mathrm{C}$. This can be explained that the low temperature condition is likely more favorable for the process of molting from megalopa to crablet1 than high temperature. The aquatic species spend less energy for metabolism at low temperatures, and the saved energy could be used for other physiological processes including the molting process (Syafaat et al., 2020). Syafaat et al. (2020) also documented that the highest survival rate from megalopa to crablet- 1 at 24 and $28^{\circ} \mathrm{C}$ was $100 \%$, but all crablet- 1 died 1 day after molting at $36^{\circ} \mathrm{C}$. In the present study, the survival rate of megalopa to crablet-1 was only $34 \%$ which was similar to the results of Do et al. (2020) that the survival rate of crabs rearing from crablet- 1 to crablet -5 at $36^{\circ} \mathrm{C}$ was also low $(12 \%)$. These results verified that the temperature of $36^{\circ} \mathrm{C}$ is not suitable for $S$. paramamosain larval rearing. The study found that the optimal temperature for rearing zoea to megalopa and megalopa to crablet-1 was similar to that published by Syafaat et al. (2021), in which the growth and survival rate of $S$. paramamosain were highest at the temperature between 28 and $30^{\circ} \mathrm{C}$. The temperature in the range of $27^{\circ} \mathrm{C}$ to $30^{\circ} \mathrm{C}$ is recommended for $S$. paramamosain larval rearing from zoea to megalopa and megalopa to crablet- 1 as it provides a high larval survival rate.

\section{CONCLUSIONS}

S. paramamosain larvae grows better at $27-30^{\circ} \mathrm{C}$ and the highest survival rate is at $27^{\circ} \mathrm{C}$. Zoeal larvae die at $33^{\circ} \mathrm{C}$ and above. Megalopa stage has a high survival rate at $27^{\circ} \mathrm{C}$ and $30^{\circ} \mathrm{C}$, but it decreases significantly at the higher temperatures. The growth rate of mud crab larvae increases with increased temperature.

\section{ACKNOWLEDGMENT}

This study was funded in part by the Can Tho University Improvement Project VN14-P6 supported by a Japanese ODA loan.

locomotor activity of blue swimmer crab Portunus pelagicus instar reared at different temperatures. $J$. Therm. Biol, 74, 234-240. 
Brett, J. R. (1979). Environmental factors and growth. In: Hoar, W. S., Randall, D. J., Brett, J. R. (Eds.), Fish Physiology. Bioenergetics and Growth, Vol. 8. Academic Press, London.

Brylawski, B. J., \& Miller, T. J. (2006). Temperaturedependent growth of the blue crab (Callinectes sapidus): A molt process approach. Canadian Journal of Fisheries and Aquatic Sciences, 63(6), 1298-1308.

Do, V. B., Do, T. T. H., Chau, T. T., Ishimatsu, A., \& Nguyen, T. P. (2018). Effect of elevated temperature on growth, survival rate, glucose, and digestive enzyme of black tiger shrimp (Penaeus monodon Fabricius, 1798) from postlarvae 15 to juvenile stages. Can Tho University Journal of Science, Aquaculture, 54(1), 99-107 (in Vietnamese).

Chen, H. C., \& Cheng, J. H. (1985). Studies on the larval rearing of serrated crab, Scylla serrata: I. Combined effects of salinity and temperature on the hatching, survival, and growth of zoae. J. Fish. Soc. Taiwan, 12, 70-77 (in Chinese with English abstract).

Hoang, D. D. (2004). Mud crab culture technique. Agriculture Publishing House (in Vietnamese).

FAO. (2007). Improving Penaeus monodon hatchery practices. Manual based on experience in Idia. FAO Fishery Technical Paper. No 446.

Tran, N. H., \& Truong, T. N. (2004). Nursing of mud crab (Scylla paramamosain) larvae at different stocking densities in green water system. Can Tho University Journal of Science, Special issue on Aquaculture, 187-192 (in Vietnamese).

Tran, N. H., \& Nguyen, T. P. (2009). Technological and economical aspects of mud crab hatcheries in the Mekong delta, Vietnam. Scientific Journal of Can Tho University, 12, 279-288.

Tran, N. H., \& Le, Q. V. (2017). Research on density reduction at different stages of crab larvae Scylla paramamosain. Scientific journal of Can Tho University: Aquaculture, 42-48 (in Vietnamese).

Tran, N. H. (2017). Determining the potential of replacing Artemia by formulated feed on growth, survival rate of mud crab (Sylla paramamosain). Scientific journal of Can Tho University: Aquaculture, 122-127 (in Vietnamese).

Tran, N. H., Le, Q. V., Tam, L. N., \& Patrick, S. (2017). Advances in research and development of mud crab (Scylla paramamosan) seed production in Mekong delta, Vietnam. In: C.I. Hendry (Eds.) Larvi - Fish \& Shellfish Larviculture Symposium 2017, Book of abstract and short communication Ghent University (pp 217-220).

Hamasaki, K. (2003). Effects of temperature on the egg incubation period, survival, and development of larvae of the mud crab Scylla serrata (Forska ${ }^{\circ}$ ) (Brachyura: Portunidae) reared in the laboratory. Aquaculture, 219, 561-572.
Hartnoll, R. G. (1982). Growth. In: D. E. Bliss \& L. G. Abele (Eds.), The biology of Crustacea, Volume 2: Embryology, morphology, and genetics, (pp. 111196). Academic Press, New York.

Heasman, M. P., \& Fielder, D. R. (1983). Laboratory spawning and mass rearing of the mangrove crab, Scylla serrata (Forskal), from first zoae to the first crab stage. Aquaculture, 34(3-4), 303-316.

Hill, B. J. (1974). Salinity and temperature tolerance of zoae of the Portunid crab Scylla serrata. Mar. Biol, $25,21-24$.

Hill, B. J. (1980). Effects of temperature on feeding activity in the crab Scylla serrata. Mar. Biol, 59, 189-192.

Do, T. T. H., \& Nguyen, V. T. (2010). Some physiological characteristics of fish and crustacean. Agricultural Publishing House Ho Chi Minh City (in Vietnamese).

Do, T. T. H., Te, T. D., Nguyen, T. E., Nguyen, T. K. H., \& Nguyen, T. P. (2020). Effects of temperatures on growth performance, survival rate, and digestive enzyme activities of mud crab juveniles (Scylla paramamosain). Can Tho University Journal of Science, Special issue on Aquaculture, 1-10 (in Vietnamese).

IPCC. (2018). Global warming of $1,5^{\circ} \mathrm{C}$. Summary for Policymakers.

Kuhn, A. A. (2017). Effects of temperature on growth and molting in blue crabs (Callinectes sapidus) and Lesser Blue Crabs (Callinectes similis) (Master's thesis). The University of Southern Mississippi.

Tran, N. D. K. (2018). Effect of probiotic (Bacillus subtilis) on water quality, survival rate, and digestive enzyme activities of mud crab larvae (Scylla paramamosain). Can Tho University Journal of Science: Aquaculture, 1-8 (in Vietnamese).

Tran, N. D. K., Nguyen, T. M., Nguyen, K. L., Ly, T. Y. M., \& Shaharom-Harrison, F. (2019). Ontogenic development of digestive enzymes of mud crab (Scylla paramamosain) during Larval Stages. Thalassas: An International Journal of Marine Sciences, 35(2), 655-661.

Leffler, C. W. (1972). Some effects of temperature on the growth and metabolic rate of juvenile blue crabs, Callinectes sapidus, in the laboratory. Marine Biology, 14(2), 104-110.

Ma, H., Jiang, W., Liu, P., Feng, N., Ma, Q., Ma, C., \& Ma, L. (2014). Identification of transcriptomederived microsatellite markers and their association with the growth performance of the mud crab (Scylla paramamosain). PloS One, 9(2), e89134.

Macintosh, D., Overton, J. L., \& Thu, H. V. T. (2002). Confirmation of two common mud crab species (Genus Scylla) in the mangrove ecosystem of the Mekong Delta, Vietnam. Journal of Shellfish Research, 21(1), 259-265. 
Mainuddin, M., Hoanh, C. T., Jirayoot, K., Halls, A. S., Kirby, M., Lacombe, G., \& Srinetr, V. (2010). Adaptation options to reduce the vulnerability of Mekong water resources, food security, and the environment to impacts of development and climate change. CSIRO: Water for a Healthy Country National Research Flagship.

Marichamy, R., \& Rapackiam, S. (November 5-8, 1991). Experimegalopant on larvae rearing and seed production of the mud crab (Scylla serrata). In: Report of the seminar on mud card and trade. Held at Surat Thani, Thailand.

Nurdiani, R., \& Zeng, C. (2007). Effects of temperature and salinity on the survival and development of mud crab, Scylla serrata (Forsskål), larvae. Aquaculture Research, 38(14), 1529-1538.

Ponce-Palafox, J., Martinez-Palacios, C. A., \& Ross, L. G. (1997). The effects of salinity and temperature on the growth and survival rates of juvenile white shrimp, Litopenaeus vannamei, Boone, 1931. Aquaculture, 157(1-2), 107-115.

Nguyen, T. P., \& Tran, N. H. (2009). Crustaceans seed production and culture technique. Can Tho University Publishing House (in Vietnamese).

Ruscoe, I. M., Shelley, C. C., \& Williams, G. R. (2004). The combined effects of temperature and salinity on the growth and survival of juvenile mud crabs (Scylla serrata Forskål). Aquaculture, 238(1-4), 239-247.

Seneriches-Abiera, M. L., Parado-Estepa, F., \& Gonzales, G. A. (2007). Acute toxicity of nitrite to mud crab Scylla serrata (Forsskål) larvae. Aquaculture Research, 38(14), 1495-1499.

Shelley, C., \& Lovatelli, A. (2011). Mud crab aquaculture: A practical manual. FAO Fisheries and Aquaculture Technical Paper (567).

Smith, S. G. (1997). Models of crustacean growth dynamics (Ph.D. dissertation). University of Maryland College Park, College Park, Md.
Syafaat, N. M, Azra, N. M, Mohamad, F., Che-Ismail, Z. C, Amin-Safwan, A., Asmat-Ullah, M., Syahnon, M., Ghazali, A., Abol-Munafi, B. A, Ma, H., \& Ikhwanuddin, M. (2021). Thermal tolerance and physiological changes in mud crab, Scylla paramamosain Crablet at Different Water Temperatures. Animals, 11(4), 1146.

Syafaat, N. M., Mohammad, S., Azra, N.M., Ma, H., Abol-Munafi, B. A., \& Ikhwanuddin (CA), M. (2020). Effect of water temperature on survival, growth and molting cycle during early crablet instar of Mud crab, Scylla paramamosain (Estampador, 1950). Thalassas: An International Journal of Marine Sciences, 36(2), 543-551.

Van-Wormhoudt, A., \& Bellon-Humbert, C. (1994). Crustacean farming: The biological basis. In: Branable, G. (Ed.). Aquaculture: Biology and Ecology of cultured species. Ellis Horwood press, 176-223.

Von-Bertalanffy, L. (1938). A quantitative theory of organic growth. Inquiries on growth laws. II. Human Biol, 10, 181-213.

Wainwright, T. C., \& Armstrong, D. A. (1993). Growth patterns in the Dungeness crab (Cancer Magister Dana): synthesis of data and comparison of models. Journal of Crustacean Biology, 13(1), 36-50.

Wang, G.Z., Li, S.J., Zeng, C. S., Lin, S. J., Kong, X. H., Ai, C. X., \& Lin, Q. W. (2005). Status of biological studies and aquaculture development of the mud crab, Scylla serrata, in China: An experimental ecological study. Aquaculture International, 13(5), 459-468.

Zeng, C., \& Li, S. (1992). Effects of temperature on survival and development of the larvae of Scylla serrata. Journal of Fisheries of China, 16(3), 213221 (in Chinese with English abstract).

Zeng, C. (2007). Induced out-of-season spawning of the mud crab, Scylla paramamosain (Estampador), and effects of temperature on embryo development. Aquaculture Research, 38(14), 1478-1485. 